\title{
Satanic or Angelic? The Politics of Religious and Literary Inspiration
}

\author{
Peter van der Veer \\ Department of Anthropology \\ University of Utrecht
}

The publication of Salman Rushdie's The Satanic Verses is clearly a major political-literary event. In India, it was banned by the Finance Minister; in Iran, the Guide of the Islamic Revolution issued a death sentence against the author and his publishers; in Holland, the Finance Minister previously not known for his literary judgment - declared that he did not like the book; and in England, "Maggie-the-bitch," whose wax image was melted in the novel, had to defend the author 'as a British citizen'. The Indian immigrant community in England, whose plight is eloquently described in the novel, sees its publication as a racist attack on its values. Indeed, as Vinay Dharwadker shows, Rushdie's magical realism makes a raid on reality, but reality hits back with a raid on fiction. Rushdie's political-literary aim seems to be accomplished. The boundaries between religion, culture, fiction - in short, between ideas - are questioned, and the game we are in is political. That sooner or later the 'imaginary world' of Rushdie's fiction would clash with the 'real world' of political power is not surprising to anyone who has read Midnight's Children (1981) or Shame (1983). The question, however, is: why does it happen now and with such vehemence? The answer must lie both in the novel itself and in the political context in which it exploded in everyone's face (including that of its author).

Rushdie's literary project refutes V. S. Naipaul's claim that Indians have to get rid of their mythical fantasies to be able to use the novel as a social and political enquiry in the real world. It is often said that Rushdie's literary device is the traditional frame-story containing myths, family chronicles and all kinds of other digressions, but to me it resembles most the Bombay Hindi movie in its emphasis on dialogue. I felt it very appropriate that Gibreel, the central character in The Satanic Verses, is a movie actor who has played all the mythological figures in Bombay's dream factory, but now starts to dream of himself as the archangel Gibreel. However, attempts are made to prevent the reader from getting lost in the dream-world. The author intrudes regularly in the text; sometimes to discuss his right to speak about the lives of others (e.g., in Shame: "Have only the dead the right to speak?"), sometimes to remind the reader that what he reads is an authored text. In The Satanic Verses, he does so at several points, but most strikingly in a vision of Gibreel, who sees God

sitting on a bed, a man of about the same age as himself, of medium height, fairly heavily built, with salt-and-pepper beard cropped close to the line of the jaw. What struck him most was that the apparition was balding, seemed to suffer from dandruff and wore glasses. This was not the Almighty he had expected. 'Who are you?' he asked with interest. 'Ooparvala', the apparition answered, The 
Fellow Upstairs'. 'How do I know you're not the other One', Gibreel asked craftily, Neechayvala, the Guy from Underneath?

In this short, funny, but, if you wish, blasphemous passage, Rushdie shows a God who strikingly resembles the author. Indeed, whatever Gibreel sees or does in dreaming or in waking originates in the imagination of his creator, so that we are reminded that we are reading a novel. This technique of intruding in the story was used in Midnight's Children and Shame to point out that the political reality of India and Pakistan was even more bizarre than what happened in the story. In The Satanic Verses, it serves a more ambitious goal: to show that there is no clear boundary between religion and fiction as products of the imagination.

This brings us to the first of a set of three interrelated themes in $\mathrm{The} \mathrm{Sa}$ tanic Verses which deserve our attention: inspiration/imagination; migration/transformation; love/jealous possessiveness. What is the difference between Muhammad's inspiration and Rushdie's imagination? A Muslim might argue that in the case of Muhammad we have absolute truth revealed to Muhammad by God through Gibreel, while Rushdie's imagination seems, at least partly, inspired by Satan. In the episode on Mahound the Messenger, the ambiguity of the revelation is shown (and as a real trickster Rushdie makes use of authentic Islamic tradition to do so). Mahound lives in a town in which three goddesses are worshipped (among them Al-Lat), while he propagates one male god, Al-Lah. The leaders of the town offer a compromise: they will worship Allah, if three of their goddesses are given the status of 'exalted birds'. Mahound accepts the compromise as a revelation of God, but later retracts it as a mistake, an inspiration from the devil: satanic verses. Another demonstration of the ambiguity of the revelation is the episode about the scribe Salman (!), who has to record the revelations as narrated by the illiterate Mahound. Salman starts to mistrust Mahound when he notices that the revelation is always to his personal advantage. Out of chagrin he begins to change the text, but it is not noticed by Mahound:

So here I was, actually writing the Book, or rewriting, anyway polluting the word of God with my own profane language. But, good heavens, if my poor words could not be distinguished from the Revelation by God's own Messenger, then what did that mean? What did that say about the quality of the divine poetry? Look, I swear, I was shaken to my soul. It's one thing to be a smart bastard and have half-suspicions about funny business, but it's quite another thing to find out that you're right.

If the sources of revelation are as ambiguous as those of fiction, the question becomes: what kind of idea is it (or in terms of the novel in which persons are ideas: what kind of idea is he?)? There appears to be a major difference between revelation and fiction. While Submission (Islam) claims the absolute Truth, Rushdie's fiction is relativistic, questions moral absolutism, and ultimately, arises from loss of faith. Prophets and writers are enemies. The scribe Salman says about Mahound: "It is his Word against 
mine" and when the poet Baal is caught and waits for his execution, he addresses Mahound: "Whores and writers, Mahound. We are the people you can't forgive. Mahound replies: Writers and whores, I see no difference here."

The second theme is that of transformation/migration. The main 'carrier' of this theme in the novel is Saladin Chamcha. When he loses his faith in his father and thereby in his religion, he decides to change his identity. He invents himself as an English gentleman, but, typically, can only find a living as an imitator of voices on television, for example in "The Aliens Show." Believing that accent conveys social identity, he marries a British wife with an upper-class accent despite her attempts to get rid of her background. This is the world of make-believe, of an attempt to assimilate, but reality is different, as Chamcha realizes when he falls from the sky on the English coast. The story that he has safely floated down from a jumbo-jet that had been blown apart above the English Channel is laughed away by the policemen who come to arrest him as an illegal immigrant. By falling on the coast instead of landing at Heathrow his carefully constructed identity falls apart. He becomes quite literally a devil with goatish features, 'demonized' by the police who treat him brutally. His wife does not want him back and so he ends up among 'his own people' in Brixhall (Brixton and Southall), where he witnesses how the police create racial riots. Thatcher's England is a long way from what he had imagined as his new homeland. In the end, he decides to make it up with his father and become Indian again. The migrant has to redefine himself, but it is not entirely a self-definition. Others redefine him also and in many cases in a racist sense. What Rushdie seems to point out is that the older self - the relation with childhood, with the father - remains a significant part of the transformation of the migrant. The language of the novel is certainly "This Angrezi I am forced to write" (in Shame), but delightfully ethnicized. It can be argued that in theme and technique there is what Michael Fischer has called "an insistence on a pluralist, multidimensional, or multifaceted concept of self" as a critique of racist and religious rhetorics of domination (Fischer 1986: 196198).

Finally, sexual relations are problematic for Rushdie's characters. In an interview I had with Rushdie for a Dutch newspaper in 1985, he argued that the relations between men and women in India and Pakistan were deeply disturbed as a result of sexual segregation. This theme is central in Shame. The daughter of General Hyder (Zia Ul Haq) is the embodiment of Shame. Her blushes can cause fire, since her shame not only goes inward, but also outward. The more her father restrains women and female sexuality through his Islamic laws, the more frightening becomes his daughter, who ends as a monster wandering through Pakistan beheading men and drawing out their entrails like a Muslim version of the Hindu goddess, Kali. The political theme of Islamic dictatorship, and the cultural theme of shame and honor are not separate. On the contrary. If you can speak of an argument in a novel, it is Rushdie's argument that the repression of women in Pakistan engenders 
other types of political repression. However, this can never succeed in the end. "It is commonly and, I believe, accurately said of Pakistan that her women are much more impressive than her men...their chains, nevertheless, are no fictions. They exist. And they are getting heavier. If you hold down one thing, you hold down the adjoining. In the end, though, it all blows up in your face." In The Satanic Verses, the poet Baal makes a dangerous satire on the sexual politics of the Prophet. He invents an imitation of Mahound's seraglio in a brothel where the twelve whores take up the names and attitudes of the twelve wives of the Messenger. It is a tremendous success amongst the males of the city who have started to complain that the Prophet is allowed to have more wives than the others. The brothel is called "The Curtain," an obvious reference to the effect on male sexual fantasies of the system of female seclusion. Islam is the religion of the male Al-Lah that subjugates the religion of the female Al-Lat. Islam is a celebration of female submission. The novel shows a relation between the ideology of seclusion and the jealous possessiveness which drives Gibreel crazy.

The Satanic Verses gives ample room to interpret it as an attack on at least two aspects of Islam: its moral absolutism and its treatment of women. Repressive ideologies of one's past, such as Islam, as well as repressive ideologies of one's present, such as racism, are the object of a cultural critique. I think that Rushdie must have had some foreboding of how such a critique would be received, although I do not want to suggest that the categories of prophet and novelist are indistinguishable. What could be expected from Imam Khomeini, who is portrayed as follows: "the Imam grown monstrous, lying in the palace forecourt with his mouth yawning open at the gates; as the people march through the gates he swallows them whole." This is an apocalyptic vision of revolutionary Iran, but not unrealistic. The Imam declares History as the creation and possession of the Devil, of the great Shaitan, the greatest of the lies - progress, science, rights and announces that

after the revolution there will be no clocks; we'll smash the lot. The word clock will be expunged from our dictionaries. After the revolution there will be no birthdays. We shall all be born again, all of us the same unchanging age in the eye of Almighty God.

A quite different vision of revolutionary Iran as Islamic paradise where everyone will be young forever, but, we must admit, much less realistic than Rushdie's vision. For Imam Khomeini, Rushdie has done the unforgivable and, if he had read the book, he could have used the words of Mahound: "Your blasphemy, Salman, can't be forgiven. Did you think I would not work it out? To set your words against the Words of God." One could say that Rushdie had already written Khomeini's part.

So much for Khomeini's Iran. My sympathies here are clearly on Rushdie's side and not only because the dictator has died already. We must, however, not make the mistake of seeing Khomeini as an isolated autocrat. 
He was an immensely popular leader of the Iranian masses, and his appeal went far beyond the boundaries of Iran. His kind of Islam is a real force in the world and we have to take sides here. Relativism is a nice thing, but there are limits. Not all Muslims followed Khomeini. In Gujarat, where I lived with Sunni Muslims during the height of the controversy, everyone condemned the death sentence. Indian Sunnis see him as a typical Shi'a who wants to usurp the place of the Prophet and as such a much greater danger for Islam than Rushdic. However, nobody had read the book and I expect that their opinion about the death sentence would change after reading it.

Rushdie has written a book which demystifies the inspiration of the Prophet and satirizes important aspects of Islam. Book burnings are not a typical reaction of Muslims to a critique of Islam. For example, V. S. Naipaul's Among the Believers did not create a reaction anywhere similar to this one. Rushdie's earlier novel Shame went far in decrying Islamic sexual politics and, though it was banned in Pakistan and some other Muslim countries, it did not raise an outcry. However, The Satanic Verses addresses what I believe to be the most basic emotion among Muslims, their devotion to the Prophet as a guideline for life, and the episode about $\mathrm{Ma}$ hound is felt as an unbearable insult to Muslim sensibilities. The reaction of Islamic nation-states to ban the book is therefore justifiable, just as is the outrage of Muslims in general. That it is not banned in secular nation-states is also justifiable, since not Islam but the freedom of expression is of crucial importance here. However, the world is not a simple sum of autonomous nation-states. This novel by an apostate Muslim from India is constructed to be an attack by the Christian West on the Islamic East. Thus constructed, it exacerbates a long-standing feeling of embattlement among Muslims, while at the same time it acts as a self-fulfilling prophecy. This is unfortunately especially the case among Muslim minorities in secular nation-states. Islamization is a transnational process recognizable all over the world among these minorities, and ironically it is fueled by a novel that deals with the construction of identity. The demonization of 'the alien' is a major concern in the novel, but its effect has been just that.

The editors of Public Culture question whether we have to take sides. I would argue that we must take sides against Khomeini's version of Islam, but certainly not against Islam. For many Muslims this novel must be offensive, and their outrage is also understandable by this non-Muslim. Nevertheless, we must take sides here for the right of an apostate Muslim to write it and for anyone who wants to read it. Whether we like it or not, the freedom to doubt is at issue here and rightly, the editors emphasize that freedom. At the same time, however, we have to take seriously the feelings of embattlement felt by many Muslims. This novel made them surface, but their origin cannot be reduced to it.

Peter van der Veer is a migrant laborer who is waiting for his 'green card' in order to assume a position as Associate Professor of Anthropology at the University of Pennsyl- 
vania (USA). At present he is a Lecturer in Anthropology at the University of Utrecht (Holland). His book Gods on Earth: The Management of Religious Experience and Identity in a North Indian Pilgrimage Centre was published in 1988 in the Monographs Series of the London School of Economics by Athlone Press.

\section{REFERENCE}

Fischer, M. "Ethnicity and the Post-Modern Arts of Memory," In J. Clifford and G. Marcus (eds.), Writing Culture (Berkeley: University of California Press, 1987). 